\title{
Acute Extremity Gangrene in COVID-19 Patients
}

\author{
Vybhav Deraje ${ }^{1, \odot}$ Rajendra S. Gujjalanavar ${ }^{1}$ Subrata Das ${ }^{2}$ Raghu Janardhan ${ }^{2}$ Pallavi Rao ${ }^{3}$
}

${ }^{1}$ Department of Plastic and Reconstructive Surgery, Sakra World Hospital, Bangalore, Karnataka, India

${ }^{2}$ Department of Internal Medicine, Sakra World Hospital, Bangalore, Karnataka, India

${ }^{3}$ Department of Laboratory Medicine, Sakra World Hospital, Bangalore, Karnataka, India

Indian J Plast Surg 2021;54:237-239.

As elective plastic surgery takes the backseat during the COVID-19 pandemic, we have noticed a pattern in the slew of referrals from the "COVID" ward of the hospital. Among the 2284 COVID-19 positive cases treated, we were asked to manage four cases of acute dry gangrene of extremities. A summary of all the patients is presented in - Table $\mathbf{1}$.

Some authors have provided early evidence of complement-mediated microvascular injury and coagulopathy in severe COVID-19 disease. ${ }^{1}$ Wang reported two critically ill patients with COVID-19-related retiform purpura, progressing to digital gangrene, who demonstrated microthrombi in the blood vessels on biopsy, elevated D-dimer levels, antithrombin III deficiency, and positive anticardiolipin IgG/IgM antibodies. ${ }^{2}$ A larger study from Italy concluded that the incidence of acute limb ischemia increased during

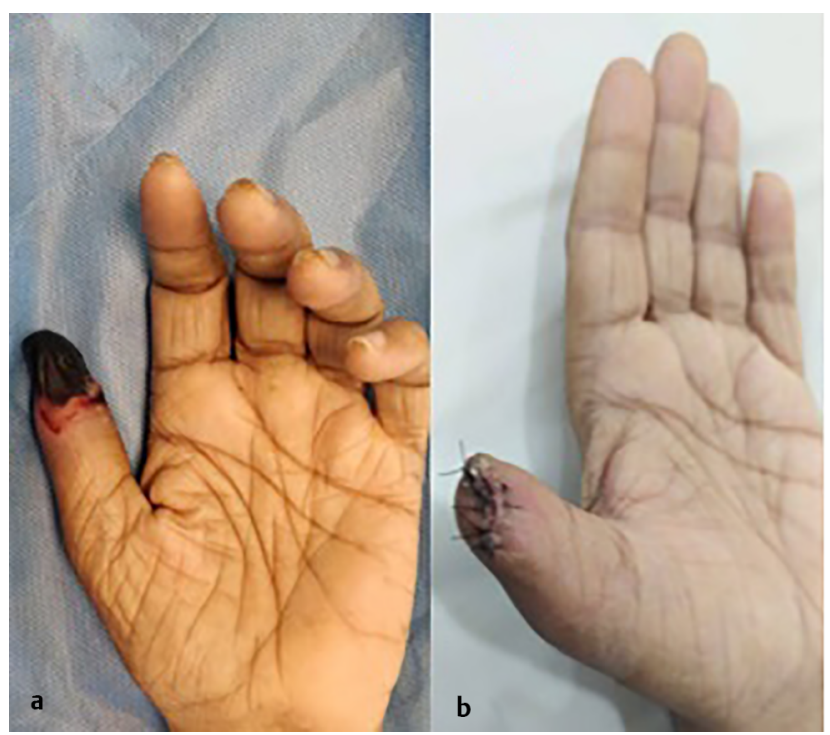

Fig. 1 Preoperative (a) and postoperative (b) pictures of patient 1.

published online

June 30, 2021
DOI https://doi.org/

$10.1055 / \mathrm{s}-0041-1731853$ ISSN 0970-0358
Address for correspondence Vybhav Deraje, MBBS, MS, DNB, Department of Plastic and Reconstructive Surgery, Sakra World Hospital, Room 2, Multi OPD, Sy No 52/2 \& 52/3, Devarabeesanahalli, Varthur Hobli, Opp Intel, Outer Ring Rd, Marathahalli, Bengaluru, Karnataka 560103, India (e-mail: vybhavd84@gmail.com).

the pandemic, and revascularization was lower than usual due to the procoagulant state. ${ }^{3}$

The common etiological factor proposed is a state of hypercoagulability, which is induced by micro- and macroangiopathy, caused by either a direct complement-mediated effect of the virus or an antibody-mediated immunological response. The delayed immunological response seems to be a logical reason for 3 of 4 patients in our series, since patients 1,2 , and 4 developed gangrene only late in the course of the disease. However, in patient 3, acute gangrene was the presenting symptom in the absence of any other typical symptoms of COVID-19 infection which, might be due to direct effect of the virus on the vasculature.

Differential diagnosis for acute ischaemia in critically ill patients include vasopressor-induced extremity gangrene, myocardial infarction (MI) with thrombi in left ventricle, hypothermia, atherosclerotic thrombi, shock, disseminated intravascular coagulation (DIC), and thrombolytic therapy. In most cases, the causation is multifactorial.

Middeldorp reported COVID-19 patients who received routine prophylactic doses of low-molecular weight heparin (LMWH) had significantly higher venous thromboembolism

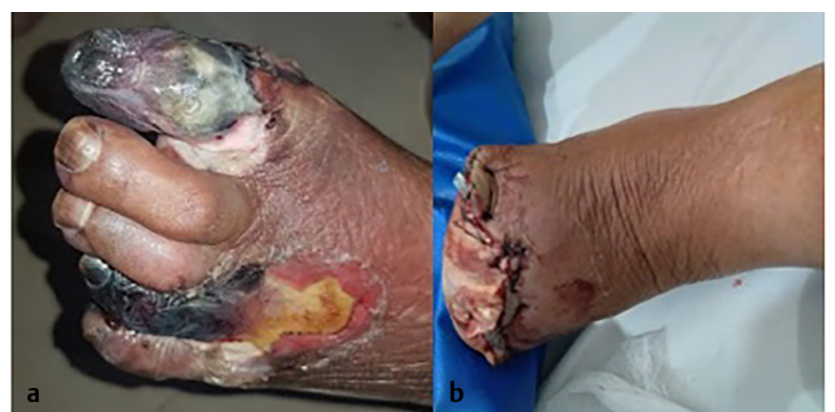

Fig. 2 Preoperative (a) and postoperative (b) pictures of patient 3.

(c) 2021. Association of Plastic Surgeons of India.

This is an open access article published by Thieme under the terms of the Creative Commons Attribution-NonDerivative-NonCommercial-License, permitting copying and reproduction so long as the original work is given appropriate credit. Contents may not be used for commercial purposes, or adapted, remixed, transformed or built upon. (https://creativecommons.org/licenses/by-nc-nd/4.0/).

Thieme Medical and Scientific Publishers Pvt. Ltd. A-12, 2nd Floor, Sector 2, Noida-201301 UP, India 
Table 1 Summary of all patients in the case series

\begin{tabular}{|c|c|c|c|c|}
\hline & Patient 1 & Patient 2 & Patient 3 & Patient 4 \\
\hline Age & 56 & 58 & 80 & 60 \\
\hline Sex & Male & Female & Male & Male \\
\hline Pattern of gangrene & Left thumb up to IP joint & Left 4th toe up to IP joint & $\begin{array}{l}\text { Left } 1 \text { st and } 4 \text { th toe up } \\
\text { to MTP joint. Left } 5 \text { th } \\
\text { toe up to IP joint }\end{array}$ & $\begin{array}{l}\text { Left foot great toe and all } \\
\text { toes of right foot-up to IP } \\
\text { joint }\end{array}$ \\
\hline $\begin{array}{l}\text { Onset of gangrene } \\
\text { (week of admission) }\end{array}$ & 6th week & 3rd week & At presentation & 3rd week \\
\hline $\begin{array}{l}\text { Management of } \\
\text { gangrene }\end{array}$ & $\begin{array}{l}\text { Revision amputation of } \\
\text { left thumb at the head } \\
\text { of proximal phalanx } \\
\text { under local anesthesia } \\
\text { (- Fig. } 2 \text { ) }\end{array}$ & Conservative & $\begin{array}{l}\text { Forefoot amputation } \\
\text { under spinal anesthesia } \\
\text { (-Fig. 1) }\end{array}$ & Conservative \\
\hline Comorbidities & Diabetes & Bronchial asthma & $\begin{array}{l}\text { Diabetes, concen- } \\
\text { tric left ventricular } \\
\text { hypertrophy }\end{array}$ & $\begin{array}{l}\text { Hypertension, bronchial } \\
\text { asthma }\end{array}$ \\
\hline Doppler & Not done & $\begin{array}{l}\text { Arterial: bilateral CFA, } \\
\text { SFA, PA, ATA, PTA, and } \\
\text { DPA are patent and show } \\
\text { normal flow and spectral } \\
\text { waveforms } \\
\text { Venous: bilateral DVT } \\
\text { (dilated, noncom- } \\
\text { pressible CFV, SFV with } \\
\text { echogenic contents } \\
\text { within suggestive of } \\
\text { DVT, dilated PV with no } \\
\text { flow within. }\end{array}$ & Not done & $\begin{array}{l}\text { Arterial: right-triphasic } \\
\text { flow in CFA and SFA. bipha- } \\
\text { sic flow in PA, ATA, PTA. } \\
\text { monophasic flow in DPA. } \\
\text { Atherosclerotic changes in } \\
\text { PA and below } \\
\text { Left-triphasic flow CFA and } \\
\text { SFA. Biphasic flow in PA. } \\
\text { Monophasic flow in ATA, } \\
\text { PTA and DPA } \\
\text { Venous: normal }\end{array}$ \\
\hline Angioplasty & Not done & Not done & $\begin{array}{l}\text { Left SFA complete } \\
\text { occlusion at origin and } \\
\text { multilevel stenosis } \\
40-50 \%\end{array}$ & Not done \\
\hline d-dimer & $\begin{array}{l}\text { Not tested in current } \\
\text { admission }\end{array}$ & Elevated & Not tested & Elevated \\
\hline Vasopressor support & No & Yes & No & Yes \\
\hline $\begin{array}{l}\text { Duration of hospital } \\
\text { stay (cumulative) }\end{array}$ & 47 days & 39 days & 2 days & 20 days \\
\hline Duration of ICU stay & 21 days & 15 days & - & 16 days \\
\hline Severity of COVID-19 a & Severe (ARDS) & Severe (septic shock) & Mild & Severe (septic shock) \\
\hline $\begin{array}{l}\text { COVID-19-related } \\
\text { complications }\end{array}$ & $\begin{array}{l}\text { Pneumonia, critical } \\
\text { care-induced neuromy- } \\
\text { opathy, grade III sacral } \\
\text { pressure sore }\end{array}$ & $\begin{array}{l}\text { Pneumonia, bilateral } \\
\text { lower limb DVT, HIT, } \\
\text { type } 1 \text { respiratory failure, } \\
\text { hyperhomocysteinemia }\end{array}$ & - & Pneumonia \\
\hline Outcome & Recovery & Recovery & Recovery & Death \\
\hline
\end{tabular}

Abbreviations: ARDS, acute respiratory distress syndrome; ATA, anterior tibial artery; CFA/CFV, common femoral artery/vein; DPA, dorsalis pedis artery; DVT, deep vein thrombosis; HIT, heparin-induced thrombocytopenia; IP, interphalangeal; MTP, metatarsophalangeal; PA/PV, popliteal artery/vein; PTA, posterior tibial artery; SFA/SFV, superficial femoral artery/vein.

a Based on Government of India guidelines-https://www.mohfw.gov.in/pdf/ClinicalManagementProtocolforCOVID19.pdf. 
rate when compared with non-COVID acutely ill patients. ${ }^{4}$ This suggests that prophylactic dose of LMWH may not be enough, and initiation of an appropriate dose of anticoagulant might be necessary. ${ }^{5}$ Initiation of therapeutic dose of LMWH in admitted COVID-19 patients (with moderate-to-severe pneumonia or d-dimer greater than $500 \mathrm{ng} / \mathrm{mL}$ ) is our current practice. We have neither seen any adverse effect of this protocol, like bleeding in our patients, nor has this been reported in literature. Those with limb ischemia and no contraindication for heparin use were treated with unfractionated heparin (UFH). We now await what difference this protocol makes in subsequent waves of the pandemic.

\section{Conflict of Interest}

None.

\section{Acknowledgments}

The authors wish to thank Mr. Abdul Majeed (Physician Assistant-Department of Plastic \& Reconstructive surgery) and Ms. Senthamarai Selvi (Plastic Surgery Nurse) for their help in data collection and documentation.

\section{References}

1 Magro C, Mulvey JJ, Berlin D, et al. Complement associated microvascular injury and thrombosis in the pathogenesis of severe COVID-19 infection: A report of five cases. Transl Res 2020;220:1-13

2 Wang JS, Pasieka HB, Petronic-Rosic V, Sharif-Askary B, Evans KK. Digital gangrene as a sign of catastrophic Coronavirus disease 2019-related microangiopathy. Plast Reconstr Surg Glob Open 2020;8(7):e3025

3 Bellosta R, Luzzani L, Natalini G, et al. Acute limb ischemia in patients with COVID-19 pneumonia. J Vasc Surg 2020;72(6):1864-1872

4 Middeldorp S, Coppens M, van Haaps TF, et al. Incidence of venous thromboembolism in hospitalized patients with COVID-19. J Thromb Haemost 2020;18(8):1995-2002

5 Schultz K, Wolf JM. Digital ischemia in COVID-19 patients: case report. J Hand Surg Am 2020;45(6):518-522 